TO OUR READERS:

\section{California Agriculture kicks off E-Edition, allowing faster publication}

$\square$ wo electronic-only articles appear in this issue, I launching California Agriculture's first E-Edition, an expanded venue for rapid publication of timesensitive findings. California appear on the website only; read them at www.californiaagriculture.anr.org by clicking "Current Issue" and scrolling down to E-Edition. Similarly, research on why California rice growers protect their harvests from contamination by trans-

"Initially, E-Edition is being offered to authors who have been waiting for publication due to our backlog," says Janet White, executive editor. "The statewide budget crisis has led to a 48-page cap on our journal. Some articles have waited a year or more for publication, an unacceptable delay."

E-Edition also means that, with this issue, the journal will change from print to electronic "version of record," the online version becoming the authoritative version to be indexed by databases and repositories. Readers can preview the abstracts and introductory comments of these articles at "E-Edition: Online" (page 159). Such "thumbnail" descriptions will appear in the print journal concurrent with each E-Edition. Space
New findings on a promising biofuel crop for genic rice appears on the website alone. permitting, E-Edition articles may be printed in a future issue.

E-Edition articles will be laid out just like print articles, with tables, figures and photographs. Readers can download and print copies in HTML or PDF format. Authors will be able to print articles on demand for distribution to target audiences.

Like all published articles, E-Edition articles will benefit from California Agriculture's augmented electronic presence (see "Indexing," page 100). The journal also appears in full on the California Digital Library and in the ANR Repository. It ranks high in Google and Google Scholar searches.

In addition, California Agriculture recently began accepting submissions via Thomson's ScholarOne peer-review management system. The new system allows authors and reviewers expanded access to Thomson's Web of Science (for ease of research and documentation) as well as other features. California Agriculture welcomes new research submissions. Go to: http://californiaagriculture.ucanr.org/ submit.cfm.

Share your comments and suggestions: Janet White, jlwhite@ucdavis.edu or (510) 665-2201 or Janet Byron, jlbyron@ucdavis.edu or (510) 665-2194. - Editors

\section{Clarification: Olive fruit fly in Mariposa County}

After our article "Understanding the seasonal and reproductive biology of olive fruit fly is critical to its management," was published in the January-March 2011 issue of California Agriculture, Cathi Boze, the agricultural commissioner in Mariposa County, noted that her county was not included as infested on the map of California on page 15. Mariposa County was not listed as trapping for olive fruit flies in the California Department of Food and Agriculture's list of counties that we used to make the map. However, Boze did indeed run traps

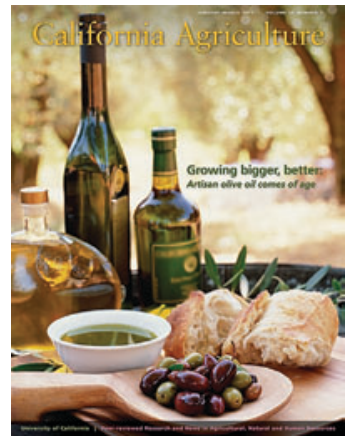

January-March 2011 California Agriculture in the county, and olive fruit flies were first detected there in 2003.

Frank Zalom

Professor, CE Specialist and Entomologist UC Agricultural Experiment Station welcomes your letters, comments and suggestions. Please write to us at: 1301 S. 46th St., Building 478 - MC 3580, Richmond, CA 94804, or calag@ucdavis.edu. Include your full name and address. Letters may be edited for space and clarity.
California Agriculture

\section{Smart sprayers pay in Australia}

I just read "Smart sprayer technology provides environmental and economic benefits in California orchards," April-June 2011. We retrofitted this system to our almond orchard sprayers for \$5,000 Australian dollars (\$5,218 U.S.) each, 4 years ago. If anything, the predicted estimates of savings are conservative. In addition to the tree sensors on our foliar sprayers, we have set up "Weed Seeker" heads on our herbicide sprayers. While these cost four times more than the tree sensors, the payback period has been similar.

Tim Orr

Lake Cullulleraine Almonds

Cullulleraine, Australia

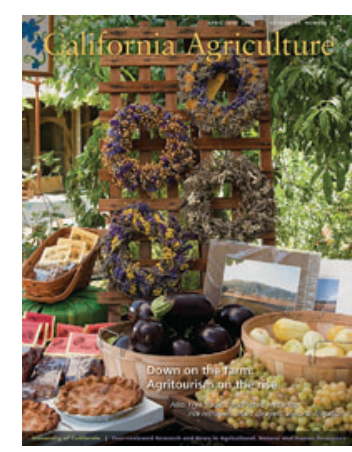

April-June 2011 California Agriculture

\section{Redwoods regenerate on 7,000-plus acres}

The Mendocino Land Trust congratulates California Agriculture on the recent article about the remarkable regrowth of redwoods at Big River ("Scientists discover redwoods' resiliency in Fritz's Wonder Plot," April-June 2011). The Fritz Wonder Plot is part of 7,334 acres of former industrial timberland that now make up the Big River unit of the Mendocino Headlands continued on page 101 